OPEN ACCESS

Edited by:

Bulent Mutus,

University of Windsor, Canada

Reviewed by:

Ann English,

Concordia University, Canada Panayiotis Orestes Vacratsis,

University of Windsor, Canada

*Correspondence:

Steven S. Gross

ssgross@med.cornell.edu

Specialty section:

This article was submitted to

Cellular Biochemistry,

a section of the journal

Frontiers in Chemistry

Received: 30 September 2015 Accepted: 11 December 2015

Published: 07 January 2016

Citation:

Nuriel T, Whitehouse J, Ma Y, Mercer EJ, Brown N and Gross SS

(2016) ANSID: A Solid-Phase Proteomic Approach for Identification and Relative Quantification of Aromatic

Nitration Sites. Front. Chem. 3:70.

doi: 10.3389/fchem.2015.00070

\section{ANSID: A Solid-Phase Proteomic Approach for Identification and Relative Quantification of Aromatic Nitration Sites}

\author{
Tal Nuriel ${ }^{1,2}$, Julia Whitehouse ${ }^{1}$, Yuliang Ma ${ }^{1}$, Emily J. Mercer ${ }^{1,3}$, Neil Brown $^{1}$ and \\ Steven S. Gross ${ }^{1 *}$ \\ ${ }^{1}$ Department of Pharmacology, Weill Cornell Medical College, New York, NY, USA, ${ }^{2}$ Department of Pathology and Cell \\ Biology, Taub Institute for Research on Alzheimer's Disease and the Aging Brain, Columbia University Medical College, New \\ York, NY, USA, ${ }^{3}$ Department of Surgery, Weill Cornell Medical College, New York, NY, USA
}

Nitration of tyrosine and other aromatic amino acid residues in proteins occurs in the setting of inflammatory, neurodegenerative, and cardiovascular diseases-importantly, this modification has been implicated in the pathogenesis of diverse diseases and the physiological process of aging. To understand the biological consequences of aromatic nitration in both health and disease, it is critical to molecularly identify the proteins that undergo nitration, specify their cognate modification sites and quantify their extent of nitration. To date, unbiased identification of nitrated proteins has often involved painstaking 2D-gel electrophoresis followed by Western Blotting with an anti-nitrotyrosine antibody for detection. Apart from being relatively slow and laborious, this method suffers from limited coverage, the potential for false-positive identifications, and failure to reveal specific amino acid modification sites. To overcome these shortcomings, we have developed a solid-phase, chemical-capture approach for unbiased and high-throughput discovery of nitrotyrosine and nitrotryptophan sites in proteins. Utilizing this method, we have successfully identified several endogenously nitrated proteins in rat brain and a total of 244 nitrated peptides from 145 proteins following in vitro exposure of rat brain homogenates to the nitrating agent peroxynitrite $(1 \mathrm{mM})$. As expected, Tyr residues constituted the great majority of peroxynitrite-mediated protein nitration sites; however, we were surprised to discover several brain proteins that contain nitrated Trp residues. By incorporating a stable-isotope labeling step, this new Aromatic Nitration Site IDentification (ANSID) method was also adapted for relative quantification of nitration site abundances in proteins. Application of the ANSID method offers great potential to advance our understanding of the role of protein nitration in disease pathogenesis and normal physiology.

Keywords: nitrotyrosine, nitrotryptophan, nitric oxide, proteomics, post-translational modifications, peroxynitrite, nitrosative stress 


\section{INTRODUCTION}

Aromatic nitration is a posttranslational modification that involves the addition of a nitro $\left(\mathrm{NO}_{2}\right)$ group to the benzene ring of an aromatic amino acid residue in proteins (Alvarez and Radi, 2003).This modification most commonly occurs during pathological conditions where high levels of reactive nitrogen species (RNS) are formed, primarily peroxynitrite $\left(\mathrm{ONOO}^{-}\right)$, arising from the near diffusion-limited reaction of nitric oxide (NO) with superoxide $\left(\mathrm{O}_{2}^{-}\right)$(Pacher et al., 2007). The most widely recognized protein aromatic nitration event occurs on Tyr residues, yielding proteinaceous 3-nitrotyrosine (3-NT), which often accumulates in the setting of neurodegenerative (Ferrante et al., 1999; Castegna et al., 2003; Sacksteder et al., 2006; Sultana et al., 2006; Reynolds et al., 2007) and cardiovascular diseases (Patel et al., 2000; Rubbo et al., 2000; Turko and Murad, 2002; Harrison et al., 2003; Peluffo and Radi, 2007), as well as during the physiological process of aging (van der Loo et al., 2000; Beal, 2002; Kanski et al., 2005b). This modification has the dual chemical consequences of both increasing the Tyr residue's steric bulk and decreasing the pKa of its hydroxyl group (from about 10.1 to 7.2 ) - potentially resulting in altered interactions with protein binding partners and/or perturbed activity of an enzyme (Abello et al., 2009). In comparison with nitration of Tyr, much less is known about the prevalence and potential effects of Trp, His, and Phe nitration in proteins. Notwithstanding, there is evidence that all of these modifications can occur under pathological conditions (Ferger et al., 2001; Ishii et al., 2007; Rebrin et al., 2007) and result in altered protein activities (Alvarez et al., 2004; Yamakura et al., 2005; Rebrin et al., 2007).

In order to elucidate the contribution that aromatic amino acid nitration plays in disease pathogenesis, it is important to recognize the relevant proteins that undergo nitration in a given pathological condition, as well as their specific sites of nitration. To date, most attempts to identify nitrated proteins in an unbiased manner have utilized 2D-gel electrophoresis using an anti-3-NT antibody (Castegna et al., 2003; Kanski et al., 2005a; Sultana et al., 2006). However, this approach possesses numerous shortcomings, including limited coverage, the potential for falsepositive identifications and failure to identify the specific sites of nitration (Kanski and Schöneich, 2005). Furthermore, since the detection of nitrated proteins is performed using a 3-NT-specific antibody, this approach is unable to identify proteins that are nitrated on aromatic amino acid residues other than Tyr.

In attempt to overcome these limitations, several groups have sought to develop an in-solution enrichment strategy for LCMS/MS based unbiased identification of nitrated proteins and their sites of nitration, similar to the SNOSID method that was developed in our laboratory for the unbiased discovery of S-nitrosylated proteins and specification of their cognate sites of Cys modification (Hao et al., 2006). These earlier attempts at establishing proteomic strategies for unbiased discovery of protein nitration sites, including some reported during the development of the present ANSID method, have demonstrated some success in identifying nitrated proteins. However, these are limited to the identification of synthesized pure nitrated proteins or peptides (Tsumoto et al., 2010), pure nitrated proteins or peptides that were spiked into complex protein mixtures (Nikov et al., 2003; Abello et al., 2010; Dremina et al., 2011; Guo et al., 2012), and relatively high concentrations of nitrated proteins or peptides that were created by $\mathrm{ONOO}^{-}$-treated human plasma (Prokai-Tatrai et al., 2011) or rat brain homogenates (Zhang et al., 2007). In addition, one method (Robinson and Evans, 2012) has accomplished the feat of detecting low-level endogenous protein nitration (in mouse spleen homogenates). However, it should be noted that this method utilized an in-house, chemically synthesized tagging reagent that would limit access to this technology.

In the current report, we describe an optimized approach with increased sensitivity and selectivity, and which utilizes inexpensive commercially available reagents, for the unbiased identification of nitrated proteins and their sites of nitration. We term this new approach the ANSID method, for Aromatic Nitration Site IDentification. Using the ANSID method, we could successfully identify endogenously nitrated rat brain protein, as well as $>100$ proteins that are most prone to peroxynitritemediated nitration, along with their cognate modification sites. Notably, these included several Trp-nitrated residues in addition to the more commonly observed Tyr-nitrated residues. As a further advance, we have used stable isotope labeling to adapt the ANSID method for relative quantification of nitration site abundance in proteins. The ANSID method offers a significant advancement over the previously reported approaches due to its ease of use, ability to specifically and sensitively recognize nitrated proteins, identify their sites of nitration, and ascertain how levels and patterns of protein nitration may change in disparate physiological and pathophysiological settings.

\section{MATERIALS AND METHODS}

\section{Reagents}

All chemicals and reagents were purchased from Sigma-Aldrich (St. Louis, MO) in the best available grade, unless otherwise noted. Rat brains, stripped of the meninges, were obtained from Pel-Freez Biologicals (Rogers, AR). Sodium peroxynitrite (100-200 $\mathrm{mM}$ in $4.7 \%$ sodium hydroxide) was obtained from EMD Millipore (Billerica, MA) and was aliquoted and stored at $-80^{\circ} \mathrm{C}$ for up to 6 months and then thawed immediately before use. Sulfo-NHS-SS-Biotin and Aminolink aldehydeagarose beads were purchased from Thermo Fisher Scientific (Waltham, MA), and Strata-X C18 columns were purchased from Phenomenex (Torrance, CA). The histone H1.2-derived peptide, ALAAAG $\left(\mathrm{Y}_{-} \mathrm{NO}_{2}\right)$ DVEK, was custom-synthesized by Genscript (Piscataway, NJ).

\section{Sample Preparation for ANSID Analysis}

For nitrated brain homogenate samples, 10 rat brains were washed 3-times with $1 \times$ PBS and placed in $15 \mathrm{ml}$ ice-cold lysis buffer (100 mM sodium phosphate, pH 7.7, $150 \mathrm{mM}$ $\mathrm{NaCl}, 0.4 \%$ Triton $\mathrm{X}-100,1 \mathrm{mM}$ protease inhibitor cocktail). Homogenization was performed on ice using a Tissue-Terror (Biospec, Bartlesville, OK) at half-maximal speed for 3 intervals of $30 \mathrm{~s}$ each. The homogenate was aliquoted into Eppendorf tubes and centrifuged $(13,400 \times g)$ for $15 \mathrm{~min}$ at $4^{\circ} \mathrm{C}$ and supernatants 
were collected. Total protein concentration was quantified with the DC protein assay (Bio-Rad), and the pooled supernatant was distributed to tubes, each containing $40 \mathrm{mg}$ of protein.

In experiments where exogenous protein nitration was performed, samples were diluted with lysis buffer to $8.75 \mathrm{ml}$ $(4.57 \mathrm{mg}$ protein $/ \mathrm{ml})$, and nitration was elicited by adding freshly-thawed $\mathrm{ONOO}^{-}$at the desired concentration and incubation for $30 \mathrm{~min}$ at room temperature with gentle rocking. Following nitration, $1.5 \mathrm{ml}$ of $20 \%$ sodium dodecyl sulfate (SDS) was added to each sample ( $4 \mathrm{mg} / \mathrm{ml}$ protein, $2.5 \% \mathrm{SDS}$ ), and proteins were denatured by boiling in a water bath for $5 \mathrm{~min}$ at $95^{\circ} \mathrm{C}$. Cys residues were then reduced with $20 \mathrm{mM}$ dithiothreitol (DTT) for $1 \mathrm{~h}$ at $60^{\circ} \mathrm{C}$ and alkylated with $80 \mathrm{mM}$ iodoacetamide for $45 \mathrm{~min}$ at room temperature in the dark. To remove excess reagents, proteins were precipitated with 2 -volumes of ice-cold acetone and pelleted by centrifugation at $2600 \times g$ for $5 \mathrm{~min}$. Protein pellets were resuspended in $7.5 \mathrm{ml}$ of $100 \mathrm{mM}$ sodium phosphate buffer, $\mathrm{pH} 7.7$ to bring the total volume up to $8 \mathrm{ml}$ $(5 \mathrm{mg}$ protein $/ \mathrm{ml})$. To digest proteins, TPCK-modified trypsin was added at a ratio of 50:1 protein:trypsin (wt:wt), and the samples were rotated overnight at room temperature.

\section{Amine-Blocking of Lys- and N-Terminal Residues and Reduction of Nitro Groups for ANSID Analysis}

Peptide extracts were aliquoted into $5 \mathrm{mg}$ quantities ( $1 \mathrm{ml}$ each) in $15 \mathrm{ml}$ tubes. Dimethylation of Lys- and N-terminal amino groups was performed by adding $100 \mathrm{mM}$ formaldehyde, $200 \mathrm{mM}$ dimethylamine borane (DMAB), and $100 \mathrm{mM}$ hydrochloric acid $(\mathrm{HCl})$ (to maintain the $\mathrm{pH}$ at $7-8$ ), with gentle mixing after the addition of each reagent, followed by incubation for $10 \mathrm{~min}$ at $60^{\circ} \mathrm{C}$ with vigorous shaking. A second round of dimethylation was then performed to ensure complete blocking of primary amines. Because formaldehyde and DMAB are highly toxic, dimethylation, as well as the following two steps, were performed under the hood. Following dimethylation, the formaldehyde/DMAB reaction was quenched by the addition of $200 \mathrm{mM}$ glycine and incubation for $10 \mathrm{~min}$ at $60^{\circ} \mathrm{C}$ with vigorous shaking. Nitro-groups present on aromatic amino acid residues were reduced to amino groups by incubating with $30 \mathrm{mM}$ DTT and $250 \mu \mathrm{M}$ hemin-agarose beads for $10 \mathrm{~min}$ in a $95^{\circ} \mathrm{C}$ water bath. Following reduction, hemin-agarose beads were removed by centrifugation at $2600 \times g$ for $2 \mathrm{~min}$, and the remaining reagents were removed by solid phase extraction (SPE) with a $30 \mathrm{mg}$ resin Strata-X C18 column. Purified peptides were eluted from the $\mathrm{C} 18$ resin with $80 \%$ acetonitrile $(\mathrm{ACN})$ in $25 \mathrm{mM}$ sodium bicarbonate, $\mathrm{pH}$ 8. Following $\mathrm{C} 18$ clean up (i.e., removal of formaldehyde and DMAB), samples were removed from the chemical hood and further steps were performed on the lab bench. Aminolink aldehyde-agarose beads were washed twice in $\mathrm{ACN}$ and then resuspended 1:1 in $80 \% \mathrm{ACN}$ in $25 \mathrm{mM}$ sodium bicarbonate, $\mathrm{pH} 8$ for peptide capture. For this purpose, $500 \mu \mathrm{l}$ of the 1:1 bead-slurry was added to each sample, and the beads were rotated for $1 \mathrm{~h}$ at room temperature. Beads were washed in the cold room (to prevent hydrolysis of the imine-bonded peptide beads) 5-times with ice-cold wash buffer \#1 (25 mM sodium bicarbonate, $600 \mathrm{mM} \mathrm{NaCl}$; pH 8.0) and then 5-times with ice-cold wash buffer \#2 (25 mM sodium bicarbonate, $20 \% \mathrm{ACN}$; $\mathrm{pH} 8.0$ ). Captured peptides were eluted by adding $500 \mu \mathrm{l}$ of $0.1 \%$ trifluoroacetic acid (TFA) and rotation for $1 \mathrm{~h}$ at room temperature. Finally, the eluted peptides were vacuum-centrifuged in a SpeedVac at $60^{\circ} \mathrm{C}$ to near-dryness and diluted to a final volume of $30 \mu 1$ with $0.1 \%$ TFA for analysis by nanoflow liquid chromatography-tandem mass spectrometry (nanoLC-MS/MS).

\section{ANSID Optimization with a Model Nitrated Peptide}

A custom-made histone H1.2-derived peptide, ALAAAG(Y$\mathrm{NO}_{2}$ )DVEK, was solubilized in $100 \mathrm{mM}$ sodium phosphate buffer ( $\mathrm{pH} 7.7$ ) at a concentration of $5 \mathrm{mg} / \mathrm{ml}$ and stored at $-80^{\circ} \mathrm{C}$ in $100 \mu \mathrm{l}$ aliquots for up to 6 months prior to use. For dimethylation and hemin/DTT-reduction of 3-NT residues, the reactions were carried out as described above. For acetylation, $100 \mu \mathrm{l}$ of the solubilized peptide was treated two times with $100 \mathrm{mM}$ acetic anhydride at $\mathrm{pH} 11$, each time with a $1 \mathrm{~h}$ incubation at $37^{\circ} \mathrm{C}$ with vigorous shaking. For sodium dithionite reduction of 3 NT residues, $100 \mu \mathrm{l}$ of the dimethylated peptide was treated with $5 \mathrm{mM}$ sodium dithionite for $10 \mathrm{~min}$ at room temperature with gentle rocking. For analysis, the peptide solution was diluted $1: 100$ in $0.1 \%$ TFA and then detected by nanoLC-MS/MS.

\section{ANSID Optimization with $\mathrm{NO}_{2}$-BSA Spiked into Untreated Rat Brain Homogenate}

Bovine serum albumin (BSA) was solubilized in $100 \mathrm{mM}$ sodium phosphate buffer, $\mathrm{pH} 7.7$, at a concentration of $4 \mathrm{mg} / \mathrm{ml}$. For nitration, $10 \mathrm{ml}$ of $4 \mathrm{mg} / \mathrm{ml} \mathrm{BSA}$ was treated with $1 \mathrm{mM}$ of freshlythawed $\mathrm{ONOO}^{-}$and the resulting samples were incubated for $30 \mathrm{~min}$ at room temperature with gentle rocking. To assess $3-$ NT peptide detection in a complex biological mixture, NO2BSA was spiked into a $4 \mathrm{mg} / \mathrm{ml}$ untreated rat brain homogenate at a concentration of $100 \mu \mathrm{g}$ NO2-BSA permg total protein. For the aldehyde-agarose bead-mediated ANSID, $5 \mathrm{mg}$ of total protein was used, and the method was performed as described above. For the Sulfo-NHS-SS-Biotin-mediated ANSID, $20 \mathrm{mg}$ of total protein was used and the ANSID was performed with several modifications. The Cys reduction and alkylation was performed as described above, followed immediately by Lys- and N-terminal dimethylation and nitro-group reduction on the intact proteins. To remove the excess reagents from proteins, each protein sample was cleaned up using a Zeba spin desalting column as described by the vendor's protocol (Thermo Fisher Scientific). The proteins were then treated with $4 \mathrm{mM}$ Sulfo-NHS-SS-Biotin for $1 \mathrm{~h}$ at $37^{\circ} \mathrm{C}$ with vigorous shaking. To reverse hydroxyl-group modifications, the samples were treated with $0.5 \mathrm{M}$ hydroxylamine at $\mathrm{pH} 8.0$ for $10 \mathrm{~min}$ at $37^{\circ} \mathrm{C}$ with vigorous shaking and were again run through a Zeba spin desalting column to remove the excess reagents. Proteins were digested overnight at room temperature with TPCK-modified trypsin at a ratio of 50:1 protein:trypsin (wt:wt), after which the reactions were stopped by addition of $500 \mu \mathrm{M}$ phenylmethylsulfonyl floride (PMSF). Prior to peptide capture, 
streptavidin-sepharose beads (GE, Piscataway, NJ) were washed twice in $25 \mathrm{mM}$ ammonium bicarbonate, $\mathrm{pH} 8.0$, and then resuspended 1:1 in $25 \mathrm{mM}$ ammonium bicarbonate, $\mathrm{pH}$ 8.0. For capture, $100 \mu \mathrm{l}$ of the 1:1 bead-slurry was added to each sample, and the beads were rotated for $1 \mathrm{~h}$ at room temperature. Beads were washed five times at room temperature with wash buffer \#1 (25 mM ammonium bicarbonate, $\mathrm{pH} 8,600 \mathrm{mM} \mathrm{NaCl}$ ) and five times with wash buffer \#2 (25 mM ammonium bicarbonate, $\mathrm{pH} 8$, $20 \%$ acetonitrile). Captured peptides were then eluted by adding $150 \mu \mathrm{l}$ of $100 \mathrm{mM} \beta$-mercaptoethanol in $15 \mathrm{mM}$ ammonium bicarbonate, $\mathrm{pH} 8$, and rotating at room temperature for $30 \mathrm{~min}$. The eluted peptides were vacuum-centrifuged to near-dryness, diluted to a final volume of $30 \mu \mathrm{l}$ with $0.1 \%$ TFA and analyzed by nanoLC-MS/MS.

\section{Isotope-Coded ANSID Approach for Relative Quantification of Nitrated Peptides}

Rat brain homogenates were treated with $1 \mathrm{mM} \mathrm{ONOO}^{-}$, as described above, and then a portion of this homogenate was diluted in untreated rat brain homogenates to give ratios of 1:1, 1:4, 1:9, or 1:19 (nitrated homogenate:non-nitrated homogenate). Samples were analyzed in quadruplicate: comparing four samples containing $5 \mathrm{mg}$ undiluted nitrated rat brain homogenate with each and four samples containing $5 \mathrm{mg}$ of $1: 1,1: 4,1: 9$, or 1:19 dilutions of nitrated rat brain homogenate in untreated rat brain homogenate. For each sample, initial steps in the ANSID was performed as described above. However, for the dimethylation step, the diluted samples were treated with $100 \mathrm{mM}$ heavy isotope-labeled formaldehyde $\left(\mathrm{C}^{13} \mathrm{D}_{2} \mathrm{O}\right.$; Sigma), while the undiluted samples were treated with only light isotopecontaining formaldehyde $\left(\mathrm{CH}_{2} \mathrm{O}\right)$. Each sample was then treated with $200 \mathrm{mM}$ glycine to quench the dimethylation reaction. At this point, each of the undiluted samples were pooled with one of the four diluted samples. The rest of the ANSID method was then continued as described above. Peptide abundances were quantified using nanoLC-MS/MS, by measuring the area under each ion current peak using Mass Hunter Qualitative Analysis software version B.03.01 (Agilent).

\section{Peptide Identification by nanoLC-MS/MS}

nanoLC-MS/MS was used to identify both the modified histone H1.2-derived peptide and the ANSID-enriched peptides from $\mathrm{NO} 2-\mathrm{BSA}$ and $\mathrm{ONOO}^{-}$-treated or untreated rat brain homogenates. Peptides were analyzed using a 6520 accurate-mass quadrupole-time of flight (Q-TOF) mass spectrometer coupled to a chip cube with an on-chip C18 column (Agilent Technologies, Santa Clara, CA). The mobile phases were $0.1 \%$ formic acid in water (solvent A) and $0.1 \%$ formic acid in $90 \%$ acetonitrile (solvent B). Eight microliters of each sample was injected onto either a $4 \mathrm{~mm} 40 \mathrm{nl}$ Zorbax 300SB-C18 or a $360 \mathrm{nl}$ Polaris 300SBC18 enrichment column at a flow rate of $4 \mu \mathrm{l} / \mathrm{min}$, and peptides were resolved on either a $0.075 \times 43 \mathrm{~mm}$ Zorbax $300 \mathrm{SB}-\mathrm{C} 18$ or a $0.075 \times 150 \mathrm{~mm}$ Polaris $300 \mathrm{SB}-\mathrm{C} 18$ analytical column at a flow rate of $0.4 \mu \mathrm{l} / \mathrm{min}$. Peptide elution utilized solvent gradients, as follows: $3-25 \%$ solvent B for $10 \mathrm{~min}$ for histone H1.2-derived peptides, $3-50 \%$ solvent $\mathrm{B}$ for $20 \mathrm{~min}$ for NO2-BSA peptides enriched using the Sulfo-NHS-SS-Biotin-mediated ANSID, $3-$ $45 \%$ solvent B for 24 min for NO2-BSA peptides enriched using the aldehyde-agarose beads-mediated ANSID and 3-40\% solvent $\mathrm{B}$ for $52 \mathrm{~min}$ for peptides from $\mathrm{ONOO}^{-}$-treated or untreated rat brain homogenates. Non-eluting peptides were then displaced by treatment with $90 \%$ solvent B for 2-5 min. Mass spectra were acquired in automated data-dependent acquisition mode at $0.5 \mathrm{~s}$ intervals, and MS/MS scans were performed on the four most intense ions for each MS scan. Peptides were identified using Spectrum Mill software version A.03.03 (Agilent). Peptide files were searched against a regularly updated Swiss-Prot database, with a peak intensity threshold of $50 \%$, precursor mass tolerance of $20 \mathrm{ppm}$ and a product mass tolerance of $50 \mathrm{ppm}$. For each sample, four separate searches were performed. In each search, a fixed modification was set for dimethylated N-terminal residues and variable modifications for carbamidomethylated Cys residues, oxidized Met residues and dimethylated Lys residues, plus an additional variable modification for either $\mathrm{NH}_{2}$ Tyr, $\mathrm{NH}_{2}$-Trp, $\mathrm{NH}_{2}$-His, or $\mathrm{NH}_{2}$-Phe residues. To assess the level of non-specific peptide capture, additional searches were performed using a reverse Swill-Prot database with a fixed monomethylated N-terminal modification or with no modification present on the N-terminal. For all searches, peptides with a Spectrum Mill score of 9 or higher were considered valid, which provides a false positive discovery rate of $<2 \%$ (calculated using a forward/reverse Swiss-Prot database).

\section{RESULTS}

The most successful previous attempts at developing an insolution enrichment strategy for unbiased identification of nitrated proteins and their cognate sites of nitration have relied on a stepwise procedure, comprising: (1) alkylation of protein or peptide amine moieties on Lys- and N-terminal amino acids, (2) chemical reduction of all aromatic ring nitro-groups to aminogroups, and (3) capture and enrichment strategies that takes advantage of the newly introduced amino group (Zhang et al., 2007; Abello et al., 2010; Tsumoto et al., 2010; Prokai-Tatrai et al., 2011; Guo et al., 2012; Robinson and Evans, 2012). The ANSID approach used in the present study followed this general strategy (Figure 1), however, our protocol was optimized and enhanced by the incorporation of novel strategies and reagents that provide increased specificity, sensitivity and relative quantification of protein nitration sites.

\section{Blocking of Lys- and N-Terminal Amines with Formaldehyde and DMAB}

In order to block Lys- and N-terminal amines, previously reported methods have employed acetylation with either acetic anhydride or NHS-acetate (Zhang et al., 2007; Abello et al., 2010; Tsumoto et al., 2010). However, this strategy interferes with the detection of Lys-containing peptides since acetylation removes a positive charge that otherwise contributes importantly to peptide ionization and detection by MS in positive ion mode (Patterson, 2001). This is especially problematic for MS-based sequencing of tryptic peptides that are cleaved C-terminally at Lys residues, and thus devoid of other basic residues that can 

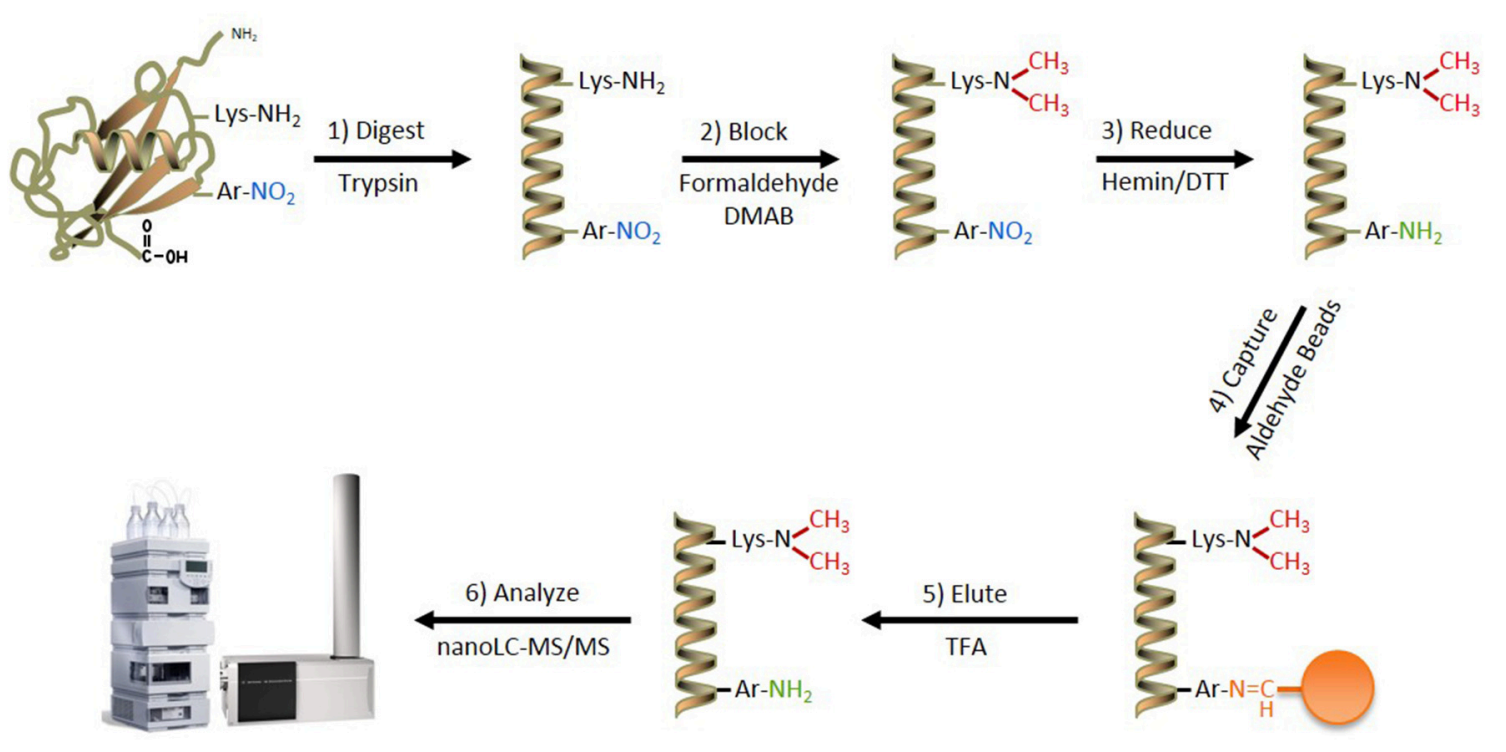

FIGURE 1 | The ANSID approach for aromatic nitration site identification. A schematic of the ANSID method. Proteins are first digested with trypsin, followed by Lys- and N-terminal amine-blocking through reductive dimethylation with formaldehyde and dimethylamine borane. The nitro-aromatic residues are then reduced to produce amines with hemin-agarose beads in the presence of DTT, followed by capture and enrichment of the amino-aromatic amino acid-containing peptides using aldehyde-agarose beads. The captured peptides are then eluted with TFA and analyzed by nanoLC-MS/MS. Abbreviations: DMAB, dimethylamine borane; DTT, dithiothreitol; TFA, trifluoroacetic acid.

potentially carry a positive charge. To assess the severity of this predicted shortcoming, we investigated the effect of acetic anhydride mediated acetylation on the detection of a synthetic histone H1.2-derived peptide, in which the only resident basic amino acid is a C-terminal Lys (Figure 2A, compare spectra a and $\mathrm{b}$ ). In accord with expectations, this peptide was no longer observed after Lys acetylation when using positive-ion LC-MS for detection.

To mitigate against this MS signal loss that arises from acetylation-induced neutralization of positive charge on amine residues of peptides, we instead utilized reductive dimethylation with formaldehyde and $\mathrm{DMAB}$ as an amine-blocking strategy. Notably, reductive dimethylation involves two sequential methylgroup additions, where each methylation is introduced via two sequential chemical steps: first, the amine group is converted to a reversible imine bond $\left(\mathrm{N}=\mathrm{CH}_{2}\right)$ by reaction with formaldehyde; second, the resulting imine is reduced to $\mathrm{N}-\mathrm{CH}_{3}$ by reaction with DMAB (Gidley and Sanders, 1982; Rayment, 1997). Because reductive dimethylation retains the amine's positive charge under acidic $\mathrm{pH}$ (Means and Feeney, 1995), sensitive identification of the modified peptides by positive ion detection mode is preserved.

As shown in Figure 2A, when the above-mentioned histone H1.2-derived model peptide was incubated with formaldehyde and $\mathrm{DMAB}$ for $10 \mathrm{~min}$ at $60^{\circ} \mathrm{C}$, we observed complete dimethylation (compare spectra a and c). Thus, in addition to allowing for retention of positive charges on Lys- and $\mathrm{N}$ terminal protein and peptide residues, reductive dimethylation with formaldehyde and DMAB was confirmed to be efficient and rapid. Furthermore, facile quenching of any unreacted formaldehyde is achieved by incubation with excess glycine, thereby eliminating the need for a sample purification step and associated sample losses that may otherwise occur.

\section{Reduction of Nitro-Groups with Hemin/DTT}

Previously published strategies for unbiased identification of nitrated proteins and sites of nitration utilized sodium dithionite for reduction of 3-NT residues to 3-aminotyrosine (3-AT) (Nikov et al., 2003; Zhang et al., 2007; Abello et al., 2010; Tsumoto et al., 2010; Dremina et al., 2011; Prokai-Tatrai et al., 2011; Guo et al., 2012; Robinson and Evans, 2012). However, as we previously showed (Nuriel et al., 2008), in addition to reducing 3-NT to 3AT in a synthetic histone H1.2-derived peptide, treatment with sodium dithionite also resulted in accumulation of a significant side-product (Figure 2B, compare spectra a to b), which we identified as a product of O-sulfation on the hydroxyl group of a newly-formed 3-AT residue, a reaction that has been previously described (Ghesquière et al., 2006). Upon further studies, we found that this sulfated and dimethylated peptide species is unavailable for reaction with amine-reactive reagents (data not shown) and accordingly, this side-reaction product precludes the identification by MS of a significant fraction of 3-AT-containing peptides.

To oppose this loss of sensitivity when using dithionite as reductant, we sought to establish an alternative approach for the reduction of aromatic nitro- to amino- groups. Previously, Balabanli et al. reported that, in the presence of thiol-containing reagents, relatively small amounts of heme-containing proteins and reagents are capable of reducing 3-NT to 3-AT when this reaction is performed at elevated temperature (Balabanli et al., 1999). Therefore, we evaluated this heme/thiol reaction for efficient nitro-reduction step in our protocol, again using the 
A

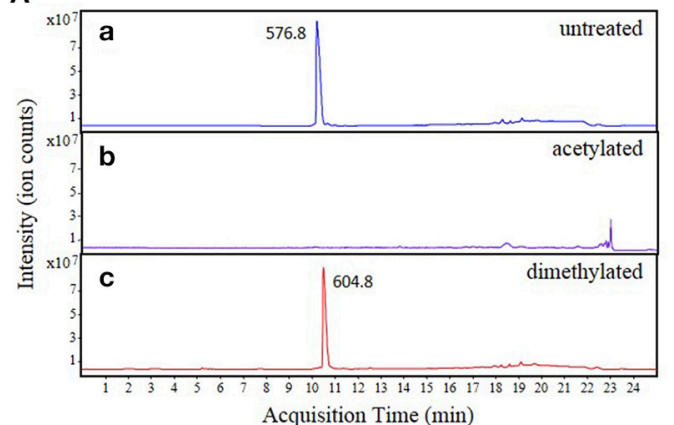

C

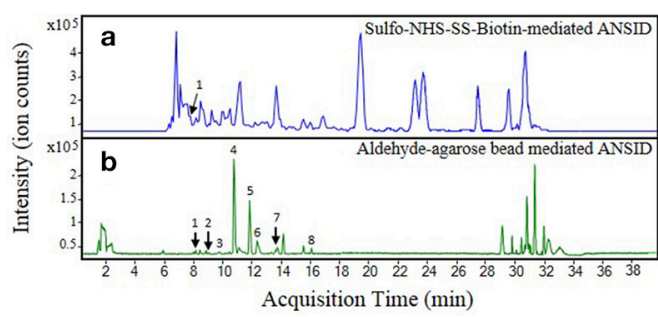

B

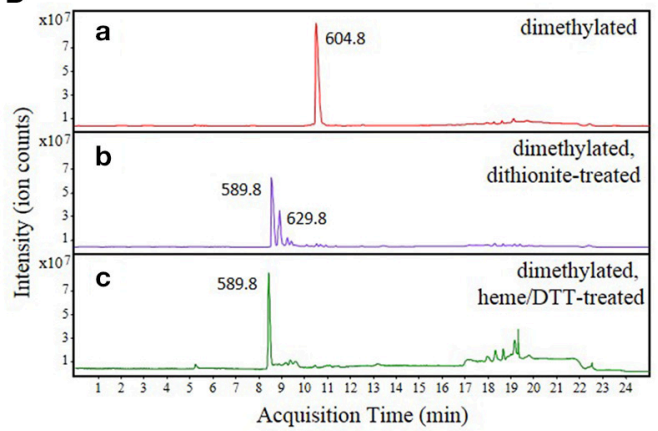

1) yLYEIAR, $\mathrm{m} / \mathrm{z} 485.78$

1) ETyGDMADccEk, m/z 517.21 5) yLYEIAR, $\mathrm{m} / \mathrm{z} 485.78$

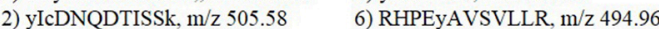

$\begin{array}{ll}\text { 3) EyEATLEEccAk, m/z } 525.24 & \text { 7) RPcFSALTPDETyVPk }, \mathrm{m} / \mathrm{z} 488.76\end{array}$

$\begin{array}{ll}\text { 4) yNGVFQEccQAEDk, } \mathrm{m} / \mathrm{z} 606.94 & \text { 8) LGEyGFQNALIVR, } \mathrm{m} / \mathrm{z} 761.92\end{array}$

FIGURE 2 | Optimization of the ANSID protocol. Base peak chromatograms (BPCs) showing the results of optimization experiments for (A) the amine-blocking step, (B) the nitro group reducing step, and (C) the amine-specific tagging/capture step. In Panel (A), a pure synthetic peptide, ALAAG(Y-NO 2$)$ DVEK (spectrum a), derived from histone $\mathrm{H1}$.2, was modified by either acetylation with acetic anhydride (spectrum b) or reductive dimethylation with formaldehyde and dimethylamine borane (spectrum c). When the unmodified peptide ( $\mathrm{m} / \mathrm{z}$ 576.8) was modified by acetylation, it became undetectable by MS (presumably due to loss of the essential positive charge), whereas reductive dimethylation resulted in the near-complete modification of the peptide to its dimethylated form (m/z 604.8) and did not interfere with its discovery by MS. In Panel (B), the nitrotyrosine group on the dimethylated histone H1.2-derived nitrated peptide (spectrum a) was reduced to aminotyrosine with either sodium dithionite (spectrum b) or hemin-agarose beads and dithiothreitol (spectrum c). While reduction with sodium dithionite caused the formation of a plus 80-dalton side product ( $\mathrm{m} / \mathrm{z}$ 629.8) in addition to the reduced dimethylated peptide ( $\mathrm{m} / \mathrm{z} 589.8)$, reduction with hemin-agarose beads and dithiothreitol resulted in near-complete reduction of nitrotyrosine without the significant formation of side-products. In Panel (C), the ANSID was performed on nitrated BSA spiked into untreated rat brain homogenate at a concentration of $100 \mu \mathrm{g} \mathrm{NO} \mathrm{N}_{2}$ BSA per mg total protein, using either amine-specific tagging with Sulfo-NHS-SS-biotin and then affinity capture with streptavidin-agarose beads (spectrum a) or direct amine-specific capture with aldehyde-agarose beads (sectrum b). While the Sulfo-NHS-SS-biotin-mediated ANSID, which was performed on 20 mg total protein, resulted in the identification of only one nitrated BSA peptide, the aldehyde-agarose-mediated ANSID, which was performed on only $1 \mathrm{mg}$ of total protein, resulted in the identification of eight nitrated BSA peptides.

histone H1.2-derived peptide to monitor reaction progression. As shown in Figure 2B (compare spectra a to c), incubating the dimethylated histone H1.2-derived peptide with hemin-agarose beads and DTT at $95^{\circ} \mathrm{C}$ for 10 min resulted in the complete reduction of 3-NT to 3-AT, with no other MS-observed sideproducts. In addition to increased efficiency of reaction, a further advantage of this hemin/DTT reduction step is that heminagarose beads can be easily removed by centrifugation, and the peptide reaction products can be efficiently purified free of residual reagents by selective binding of peptides to a $\mathrm{C} 18$ spin-column.

\section{Capture of Amino-Aromatic Amino Acid-Containing Peptides with Aldehyde-Agarose Beads}

Previously published methods for unbiased identification of nitrated proteins and sites of nitration have utilized some form of N-hydroxysuccinimide (NHS)-containing reagent to either tag or directly capture the 3-AT-containing proteins or peptides that result after 3-NT reduction (Nikov et al., 2003; Zhang et al., 2007; Tsumoto et al., 2010; Prokai-Tatrai et al., 2011; Guo et al., 2012).
However, in addition to reacting with primary amines, NHS reagents can also react non-specifically with the guanidinium groups of Arg residues (Miller et al., 1997) and with the hydroxyl groups of Ser, Thr, and Tyr residues that lie in close proximity to His residues (Miller, 1996; Miller et al., 1997; Kalkhof and Sinz, 2008).

To test the efficiency of NHS-containing reagents for use in an amine-specific enrichment step, we assessed the utility of this strategy for detection of 3-NT in $1 \mathrm{mM} \mathrm{ONOO}^{-}$-treated BSA spiked into untreated rat brain homogenate (at a concentration of $100 \mu \mathrm{g}$ NO2-BSA per mg total protein). As described in Materials and Methods Section, we performed a modified ANSID approach on the $\mathrm{NO}_{2}$-BSA/rat brain homogenate mixture that included the affinity tagging of amino-aromatic groups with Sulfo-NHSSS-biotin, followed by capture of the biotinylated peptides with streptavidin-sepharose beads. As shown in Figure 2C (spectrum a), using this Sulfo-NHS-SS-biotin-mediated ANSID approach we were only able to identify a single nitrated BSA peptide by MS, and this was only achieved with a large amount $(20 \mathrm{mg})$ of total protein.

Due to the apparent inefficiency of this Sulfo-NHS-SS-biotinmediated ANSID, we searched for an alternative amine-reactive 
reagent that could be used for more efficient enrichment. Since our initial amine-blocking step utilized reductive dimethylation with formaldehyde and DMAB, we sought to evaluate the potential of a similar aldehyde-driven mechanism for aminespecific enrichment. As described previously, aldehyde reagents can be used to create a stable covalent bond with primary amines through a two-step mechanism, wherein the aldehyde reagent first reacts with the amine to form a labile imine bond, and then a borane reagent is used to reduce that imine bond to an stable bond. However, because we require the captured peptides to be eluted for shotgun identification by MS, an irreversible covalent linkage would not serve for our enrichment step. Instead, we hypothesized that if we captured the amino-aromatic-containing peptides with aldehyde-agarose beads in the absence of a borane reagent (thus stopping the reaction after the formation of the labile imine bond), we could wash away non-specifically-bound peptides in the cold (i.e., at $4^{\circ} \mathrm{C}$, to limit hydrolysis of the imine bond), followed by elution of the captured peptides at acidic pH. Notably, because these acid-eluted peptides would possess an amine moiety on their formerly nitrated aromatic amino acid residues, they can be distinguished from unmodified aromatic amino acids by LC-MS/MS.

As with the Sulfo-NHS-SS-biotin-mediated ANSID, we tested this aldehyde-agarose-mediated ANSID using $1 \mathrm{mM} \mathrm{ONOO}^{-}$treated BSA spiked into untreated rat brain homogenate at a concentration of $100 \mu \mathrm{g}$ NO2-BSA permg total protein. As shown in Figure 2C (spectrum b), performing the ANSID using aldehyde-agarose beads resulted in markedly greater specificity and selectivity than had previously been obtained with the SulfoNHS-SS-biotin reagent. Indeed, with this strategy, we were able to identify 8 nitrated BSA peptides from only $1 \mathrm{mg}$ of total protein, meaning that the use of direct capture with aldehyde-agarose beads resulted in both greatly improved specificity/selectivity, as compared with the NHS-mediated tagging method.

\section{Identification of Nitrated Proteins and Their Nitration Sites in Untreated and Peroxynitrite-Treated Rat Brain Homogenate}

The fully optimized ANSID protocol is depicted in Figure $\mathbf{1}$ and proceeds as follows: (1) digestion of proteins with trypsin, (2) dimethylation of Lys- and N-terminal amines on peptides with formaldehyde/DMAB, (3) reduction of aromatic nitro groups to amino groups with hemin/DTT, (4) capture of amino-aromatic amino acid-containing peptides with aldehyde-agarose beads, (5) peptide elution with TFA, and (6) analysis by LC-MS/MS. In order to test the utility of this method for the discovery of nitrated proteins and their nitration sites in a complex biological mixture, we performed the ANSID on rat brain homogenates that were either untreated or nitrated by treatment with $250 \mu \mathrm{M}$ or $1 \mathrm{mM} \mathrm{ONOO}{ }^{-}$. For each group, the ANSID was performed on six replicate rat brain homogenates, and all of the nitrated peptides that were identified in at least two of the six replicates are listed in Table 1 (untreated), Table $2\left(250 \mu \mathrm{M} \mathrm{ONOO}^{-}\right)$and Supplementary Table $1\left(1 \mathrm{mM} \mathrm{ONOO}^{-}\right)$.

In total, we identified 3 nitrated peptides from 3 proteins that were identified in at least two of the six replicates from the untreated rat brain homogenates, 19 nitrated peptides from 13 proteins in $250 \mu \mathrm{M} \mathrm{ONOO}^{-}$-treated rat brain homogenates and 244 nitrated peptides from 145 proteins in $1 \mathrm{mM} \mathrm{ONOO}^{-}$treated rat brain homogenates. While $99 \%$ of the nitrated peptides identified in the $1 \mathrm{mM} \mathrm{ONOO}^{-}$-treated rat brain homogenates were nitrated on a Tyr residue, we also identified 2 peptides that were nitrated on a Trp residue. These Trp-nitrated peptides, as well as the 3 Tyr-nitrated peptides identified in untreated rat brain homogenates, were all manually validated through analysis of their MS/MS spectra and their identity was confirmed (Figure 3). To our knowledge, these results mark the first time that an in-solution enrichment method has identified Trp-nitrated proteins in a biologically-complex protein mixture.

\section{Modification of the ANSID for Relative Quantification of Nitrated Peptides}

Because nitration levels may be predicted to vary with disease progression and in response to therapeutic treatments, the capability to monitor changes in nitration levels of specific proteins and sites will be critical for determining the significance of aromatic ring nitration for disease progression/regression. However, MS is not an inherently quantitative technique, and the number of ion counts per pmol of any identified peptide will be highly dependent on relative ionization and competition for ionization (ion suppression) by co-eluting species (Ong and Mann, 2005). One way to overcome this limitation is to perform isotope-labeling, where one sample is labeled with a reagent that contains the common light isotope of hydrogen and/or carbon, and the other samples is labeled with the identical reagent, but containing a heavy isotope (i.e., deuterium and/or carbon-13). This heavy/light labeling is followed by sample pooling and concurrent further processing. Finally, samples

TABLE 1 | Nitrated peptides identified in untreated rat brain homogenate (Spectrum Mill score of $\geq 9$, corresponding to a false positive rate of $<2 \%$ ).

\begin{tabular}{|c|c|c|c|c|c|c|}
\hline Protein & Accession \# & References & Peptide & References & $\begin{array}{c}\text { Samples } \\
\text { present }\end{array}$ & $\begin{array}{c}\text { Average } \\
\text { score }\end{array}$ \\
\hline $\begin{array}{l}\text { 14-3-3 protein } \\
\text { gamma }\end{array}$ & $\underline{P 61983}$ & Sultana et al., 2007 & (K)TAFDDAIAELDTLNEDSYK(D)* & & 2 & 15.60 \\
\hline Actin, cytoplasmic & $\underline{P 60711}$ & $\begin{array}{l}\text { Zhang et al., 2007; } \\
\text { Ghesquière et al., } 2009\end{array}$ & (R)kDLYANTVLSGGTTMYPGIADR(M) & $\begin{array}{l}\text { Zhang et al., 2007; } \\
\text { Ghesquière et al., } 2009\end{array}$ & 3 & 20.24 \\
\hline Seipin & Q5FVJ6 & & (R)SVmLHYR(S) & & 6 & 12.46 \\
\hline
\end{tabular}

*Dimetylated lysine residues are denoted by lower case " $k$ " and nitrated tyrosine residues are denoted by red upper case $Y$. 


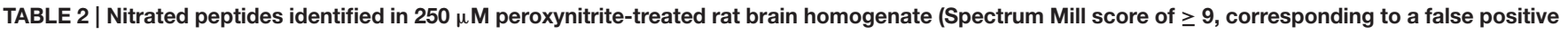
rate of $<2 \%$ ).

\begin{tabular}{|c|c|c|c|c|c|c|}
\hline Protein & Accession \# & References & Peptide & References & $\begin{array}{l}\text { Samples } \\
\text { present }\end{array}$ & $\begin{array}{c}\text { Average } \\
\text { score }\end{array}$ \\
\hline $\begin{array}{l}\text { 14-3-3 protein } \\
\text { beta/alpha }\end{array}$ & $\underline{\text { P35213 }}$ & $\begin{array}{l}\text { Zhang et al., 2007; } \\
\text { Ghesquière et al., } 2009\end{array}$ & $(\mathrm{~K})$ TAFDEAIAELDTLNEESYK(D)* & $\begin{array}{l}\text { Zhang et al., 2007; } \\
\text { Ghesquière et al., } 2009\end{array}$ & 2 & 15.60 \\
\hline 14-3-3 protein epsilon & $\underline{P 62260}$ & $\begin{array}{l}\text { Zhang et al., 2007; } \\
\text { Ghesquière et al., } 2009\end{array}$ & (K)AAFDDAIAELDTLSEESYK(D) & $\begin{array}{l}\text { Zhang et al., 2007; } \\
\text { Ghesquière et al., } 2009\end{array}$ & 3 & 20.24 \\
\hline 14-3-3 protein theta & $\underline{P 68255}$ & Zhang et al., 2007 & (K)TAFDEAIAELDTLNEDSYk(D) & Zhang et al., 2007 & 6 & 12.46 \\
\hline $\begin{array}{l}\text { 14-3-3 protein } \\
\text { zeta/delta }\end{array}$ & $\underline{P 63102}$ & $\begin{array}{l}\text { Zhang et al., 2007; } \\
\text { Stevens et al., } 2008\end{array}$ & $\begin{array}{l}\text { (K)TAFDEAIAELDTLSEESYk(D) } \\
\text { (R)YLAEVAAGDDk(K) }\end{array}$ & $\begin{array}{l}\text { Zhang et al., } 2007 \\
\text { Stevens et al., 2008; } \\
\text { Ghesquière et al., } 2009\end{array}$ & $\begin{array}{l}6 \\
2\end{array}$ & $\begin{array}{l}18.41 \\
12.74\end{array}$ \\
\hline $\begin{array}{l}\text { Glutamate } \\
\text { dehydrogenase 1, } \\
\text { mitochondrial }\end{array}$ & $\underline{P 10860}$ & $\begin{array}{l}\text { Aulak et al., 2001; } \\
\text { Reed et al., } 2009\end{array}$ & (K)VYEGSILEADcDILIPAASEk(Q) & & 5 & 15.16 \\
\hline $\begin{array}{l}\text { Hemoglobin subunit } \\
\text { alpha-1/2 }\end{array}$ & $\underline{P 01946}$ & Li et al., 2011 & $\begin{array}{l}\text { (K)TYFSHIDVSPGSAQVK(A) } \\
\text { (K)IGGHGGEYGEEALQR(M) }\end{array}$ & Li et al., 2011 & $\begin{array}{l}6 \\
4\end{array}$ & $\begin{array}{l}16.83 \\
16.22\end{array}$ \\
\hline $\begin{array}{l}\text { Hemoglobin subunit } \\
\text { beta-1 }\end{array}$ & $\underline{P 02091}$ & $\begin{array}{l}\text { Zhang et al., 2007; Li } \\
\text { et al., } 2011\end{array}$ & (R)YFDSFGDLSSASAImGNPk(V) & & 5 & 13.12 \\
\hline \multirow[t]{2}{*}{ Myelin basic protein $\mathrm{S}$} & $\underline{\mathrm{P} 02688}$ & $\begin{array}{l}\text { Zhang et al., 2007; } \\
\text { Stevens et al., } 2008\end{array}$ & (K)YLATASTMDHAR(H) & $\begin{array}{l}\text { Zhang et al., 2007; } \\
\text { Stevens et al., } 2008\end{array}$ & 5 & 15.92 \\
\hline & & & (R)TTHYGSLPQk(S) & Zhang et al., 2007 & 3 & 14.13 \\
\hline $\begin{array}{l}\text { Phosphoglycerate } \\
\text { mutase } 1\end{array}$ & $\underline{P} 25113$ & $\begin{array}{l}\text { Zhang et al., 2007; } \\
\text { Ghesquière et al., } \\
\text { 2009; Reed et al., } 2009\end{array}$ & (R)FSGWYDADLSPAGHEEAk(R) & & 5 & 17.87 \\
\hline $\begin{array}{l}\text { Pyruvate kinase } \\
\text { isozymes M1/M2 }\end{array}$ & $\underline{P 11980}$ & $\begin{array}{l}\text { Kanski et al., 2005b; } \\
\text { Ghesquière et al., } 2009\end{array}$ & $\begin{array}{l}\text { (K)ITLDNAYMEk(C) } \\
\text { (R)LNFSHGTHEYHAETIk(N) }\end{array}$ & $\begin{array}{l}\text { Kanski et al., 2005b; } \\
\text { Ghesquière et al., } 2009\end{array}$ & $\begin{array}{l}5 \\
3\end{array}$ & $\begin{array}{l}10.64 \\
19.75\end{array}$ \\
\hline Synapsin-2 & $\underline{Q 63537}$ & & (K)VENHYDFQDIASWALTQTYATAEPFIDAK(Y) & & 2 & 10.05 \\
\hline Tubulin alpha-1B chain & $\underline{P 68370}$ & $\begin{array}{l}\text { Zhang et al., 2007; } \\
\text { Ghesquière et al., } 2009\end{array}$ & $\begin{array}{l}\text { (R)FDGALNVDLTEFQTNLVPYPR(I) } \\
\text { (R)LSVDYGK(K) }\end{array}$ & $\begin{array}{l}\text { Zhang et al., } 2007 \\
\text { Ghesquière et al., } 2009\end{array}$ & $\begin{array}{l}2 \\
2\end{array}$ & $\begin{array}{l}10.99 \\
9.69\end{array}$ \\
\hline Tubulin beta-2A chain & $\underline{P 85108}$ & $\begin{array}{l}\text { Zhang et al., 2007; } \\
\text { Stevens et al., } 2008\end{array}$ & $\begin{array}{l}\text { (K)GHYTEGAELVDSVLDVRR(K) } \\
\text { (K)LTTPTyGDLNHLVSATMSGVTTLLR(F) }\end{array}$ & Stevens et al., 2008 & $\begin{array}{l}6 \\
2\end{array}$ & $\begin{array}{c}15.24 \\
13.5\end{array}$ \\
\hline
\end{tabular}

*Dimetylated lysine residues and carbimethylated cystene residues are denoted by lower case " $k$ " and "c", respectively. Nitrated tyrosine residues are denoted by a red upper case $Y$.

are analyzed by LC-MS/MS for ratiometric comparison of the isotopic abundances of all the observed peptides (Gevaert et al., 2008). With this strategy, differentially-labeled peptides will elute from the LC column at identical retention times and MS detection sensitivities, but distinguishable from one another based on distinct mass-to-charge $(\mathrm{m} / \mathrm{z})$ ratios.

Using this isotopic labeling approach, we created a ratiometric quantitative ANSID technique by utilizing heavy and light formaldehyde for dimethylation of the Lys- and N-terminal amino groups during the amine-blocking step. The heavy formaldehyde was $>98 \%$ enriched with one carbon-13 and two deuterium atoms, giving it a total mass difference of $+3 \mathrm{Da}$ over the standard light formaldehyde, which was $>98 \%$ enriched with one carbon-12 atom and two hydrogen atoms. Since the dimethylation step used in our method ultimately results in the incorporation of two carbon atom and four hydrogen atoms from formaldehyde per labeled amino acid, dimethylation with heavy formaldehyde predictably results in a mass shift of $+6 \mathrm{Da}$ for tryptic peptides containing a C-terminal Arg residue (where only the $\mathrm{N}$-terminal amine is modified) and $+12 \mathrm{Da}$ for peptides containing a C-terminal Lys residue (where both the N-terminal amine and amino group in Lys are modified).
In order to test this strategy for quantitative ANSID, we compared the relative levels of nitrated peptides detected in undiluted rat brain homogenates vs. homogenates diluted to varying extents with exogenously nitrated brain homogenates. Specifically, nitrated peptides were extracted from undiluted rat brain homogenate exposed to $1 \mathrm{mM} \mathrm{ONOO}^{-}$, compared to with untreated rat brain homogenate diluted $1: 1,1: 4,1: 9$, or $1: 19$ with the nitrated peptide homogenate. For this quantitative ANSID procedure, the non-nitrated sample was dimethylated using light formaldehyde, while the nitrated samples were dimethylated using heavy formaldehyde. Afterwards, the dimethylation reactions were quenched by incubation with glycine, and each undiluted sample was pooled with one of the four diluted samples for processing and analysis by LC-MS/MS.

To assess the linearity for quantification in this experiment, we considered the 10 most abundant nitrated peptides and determined the relative quantities (comparing ion counts) for light vs. heavy versions of these peptides in each of the pooled mixtures $(n=4)$. As shown in Figure $\mathbf{4 A}$, the observed ratios of heavy vs. light nitrated peptides were found to be in accord with the predicted ratios for each dilution, with an average observed heavy:light ratio of 0.502 for the 1:1 dilution (0.326-0.644 range), 
A
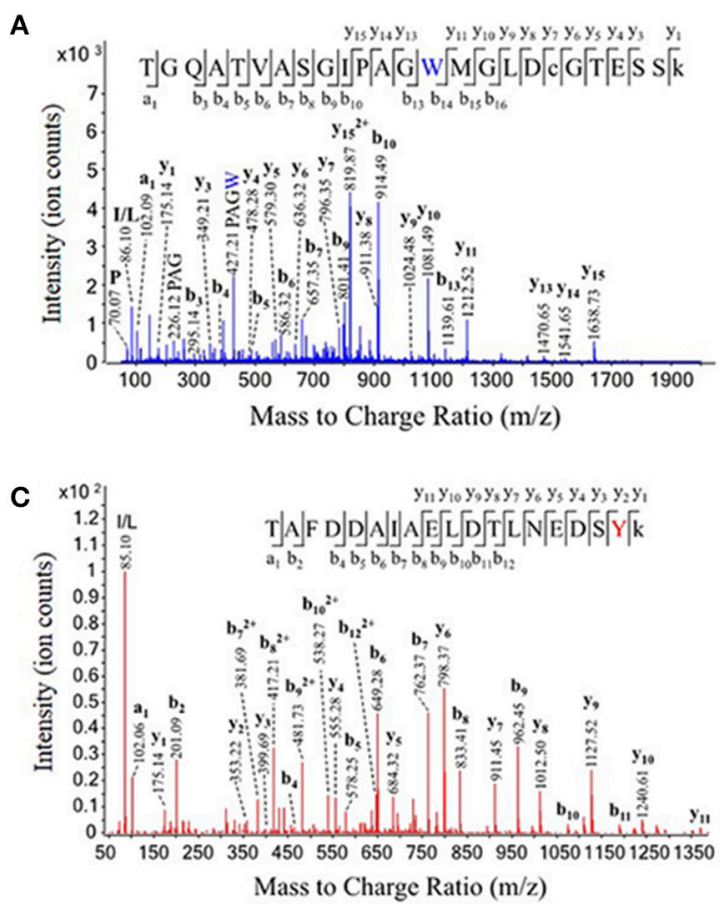

B
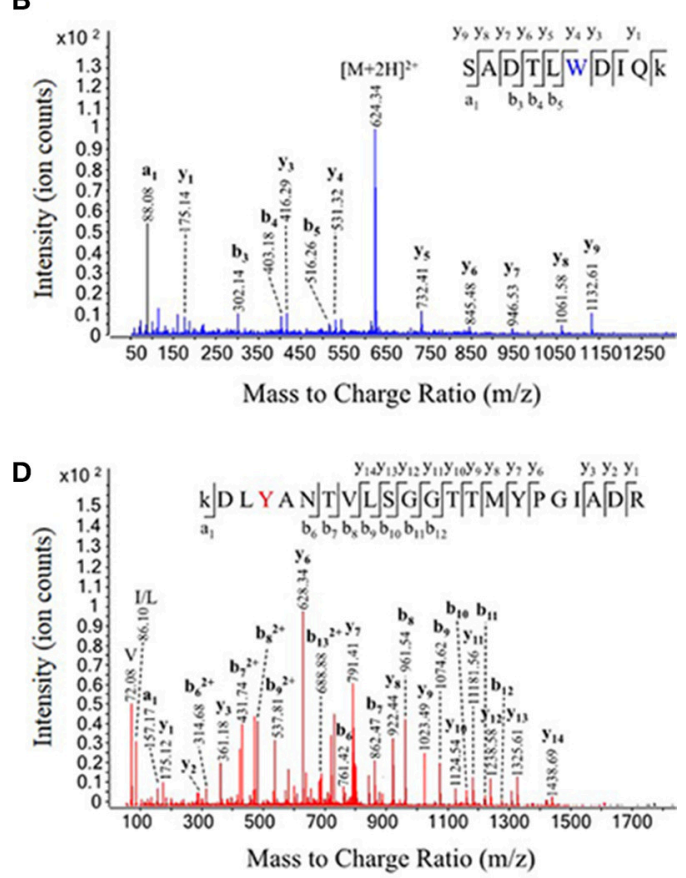

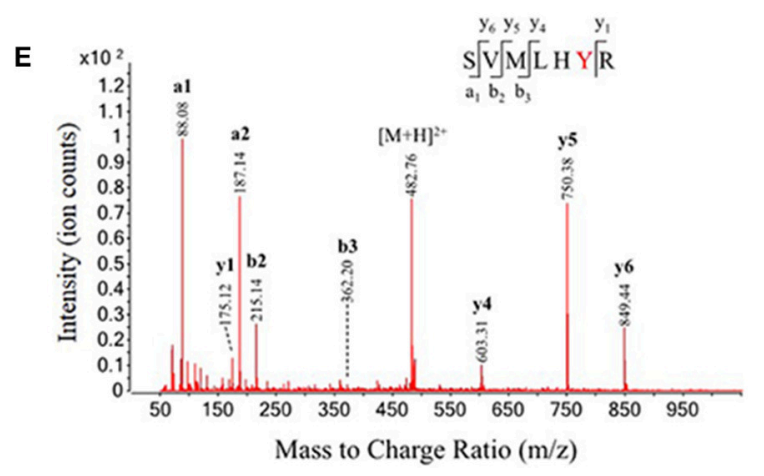

FIGURE 3 | Validation of tryptophan nitration sites in peroxynitrite-treated rat brain homogenate and tyrosine nitration sites in untreated rat brain homogenate. The labeled MS/MS spectra from five nitrated peptides. The identities of each of the two tryptophan nitrated peptides discovered in the $1 \mathrm{mM}$ $\mathrm{ONOO}^{-}$-treated brain homogenates $(\mathbf{A}, \mathbf{B})$ and each of the three tyrosine nitrated peptides discovered in the untreated rat brain homogenates (C-E) were manually validated using their MS/MS fragmentation data. Dimethylated lysines and carbamidomethylated cysteines are represented by under case letters, and nitration sites are represented by colored letters.

0.202 for the $1: 4$ dilution (0.146-0.271 range), 0.096 for the $1: 9$ dilution (0.068-0.120 range), and 0.058 for the $1: 19$ dilution (0.046-0.093 range). Furthermore, as shown in Figure 4B, it is clear that while the equivalent heavy and light peptides co-elute, there is enough separation on the $\mathrm{m} / \mathrm{z}$ axis to easily differentiate between them, even for peptides with only one dimethylation group, such as the rat brain peptide GHyTEGAELVDSVLDVVR.

\section{DISCUSSION}

The lack of a robust method for enriching and identifying nitrated proteins from endogenously nitrated tissues represents a significant obstacle in the study of how protein nitration impacts human physiology and pathology. Although the global levels of nitration in a given disease state can be easily quantified with applications such as high-performance liquid chromatography with electrochemical detection (HPLC-ECD) (Nuriel et al., 2008; Zhou et al., 2011) and multiple-reaction monitoring (MRM) MS (Ishii et al., 2006; Danielson et al., 2009), it is difficult to investigate the true impact of protein nitration without the knowledge of which specific proteins become nitrated in various settings and on which specific amino acid residues. In this report, we describe a new method for identifying both exogenously and endogenously nitrated proteins and their sites of nitration. We anticipate that application of this method will provide a significant step forward in efforts to specifically identify and provide a relative quantification of nitration sites in settings of health and disease. The ANSID approach proceeds through a simple and straightforward protocol (Figure 1) that results in the enrichment of nitrated peptides from complex proteolytic 

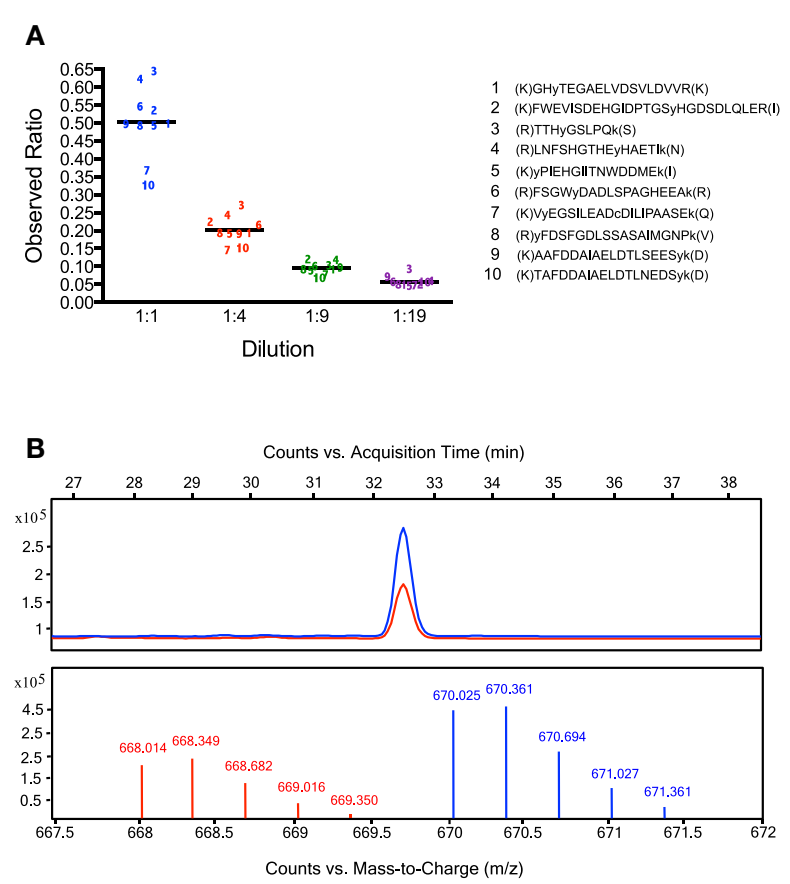

FIGURE 4 | Relative quantification of nitrated rat brain peptides using dimethylation with heavy and light formaldehyde. Results from

experiments comparing the relative quantities of nitrated peptides extracted from undiluted vs. diluted samples of nitrated rat brain homogenate. Panel (A) depicts the observed vs. expected ratios in each dilution group of the 10 most abundant nitrated peptides. Each observed ratio value is the mean value from three replicate experiments. The average observed ratios are 0.502 for the $1: 1$ dilution, 0.202 for the 1:4 dilution, 0.096 for the $1: 9$ dilution, and 0.058 for the 1:19 dilution. In Panel (B), the chromatograms from the purified heavy and light versions of the nitrated rat brain peptide GHyTEGAELVDSVLDVVR are shown. As this peptide is triply charged and contains just one dimethylation site (the $\mathrm{N}$-terminus), the $\mathrm{m} / \mathrm{z}$ difference between the heavy and light peptides is +2 ( $6 \mathrm{Da} / 3$ charges). Though these equivalent peptides co-elute, they clearly separate from one another on the $\mathrm{m} / \mathrm{z}$ axis.

mixtures for identification by LC-MS/MS. Although similar methods have been previously reported (Nikov et al., 2003; Zhang et al., 2007; Abello et al., 2010; Tsumoto et al., 2010; Dremina et al., 2011; Prokai-Tatrai et al., 2011; Guo et al., 2012), the utility of these methods has been essentially limited to the identification of small amounts of nitrated proteins from exogenously nitrated samples. In addition, the majority of these methods could not be employed for relative nitrated peptide quantification and could only identify peptides/proteins containing 3-NT residues, and not those nitrated on other aromatic amino acids.

In developing this ANSID method, we hypothesized that the limited effectiveness of the previously described methods arise from inefficiencies of the reagents and methodologies utilized. Therefore, we focused our efforts on optimizing each individual step in the enrichment protocol to achieve maximal selectivity and yield. Over the course of our optimization efforts, we identified multiple enhancements relative to the in-solution enrichment strategies that had been previously employed. Indeed, for the amine-blocking step, we found that reductive dimethylation with formaldehyde and DMAB allowed for the rapid and efficient modification of primary amines and, unlike acetylation, this reaction did not remove their positive charge at acidic $\mathrm{pH}$ and thereby enabled sensitive MS detection (Figure 2A). For the nitro-group reduction step, we found that heating samples in the presence of heminagarose beads and DTT resulted in essentially complete reduction of 3-NT to 3-AT and did not result in the generation of significant side-products, as was the case for reduction with sodium dithionite (Figure 2B). And for the capture of the resulting amino-aromatic containing peptides, we found that solid-phase capture with aldehyde-agarose beads was more effective at enriching 3-AT-containing peptides from an NO2-BSA/rat brain homogenate mixture, compared to affinity-tagging with Sulfo-NHS-SS-Biotin, followed by a streptavidin-sepharose bead capture (Figure 2C). Importantly, all of these optimized strategies utilize inexpensive, commercially available reagents.

It is interesting to note that the solid-phase capture strategy utilized in the ANSID was also employed to improve upon the SNOSID method for identifying S-nitrosylated proteins/sites, allowing for endogenously S-nitrosylated proteins to be identified in large numbers for the first time (Doulias et al., 2010). It should also be noted that a similar reductive dimethylation strategy was employed for the amine-blocking step in an in-solution effort to identifying nitrated proteins and their sites of nitration by Prokai-Tatrai et al. (2011). Abello et al. reported the use of a similar heme/DTT reduction of 3-NT residues in their insolution enrichment method (Abello et al., 2010). The ANSID approach described herein assembles what we have found to be the most efficacious and optimized procedural steps for detection of protein nitration sites and additionally provides for their relative quantification.

Once optimized, we utilized the ANSID method to identify nitrated proteins in exogenously nitrated rat brain homogenates. In $1 \mathrm{mM} \mathrm{ONOO}^{-}$-treated rat brain homogenates, we discovered 244 nitrated peptides from 145 proteins (Supplementary Table 1), with 6 of these proteins being isoforms of 14-3-3. These identified proteins are involved in a wide range of cellular functions, including cell signaling, energy metabolism, protein transport, and host defense. Out of the 145 total nitrated proteins identified in the $1 \mathrm{mM} \mathrm{ONOO}^{-}$-treated homogenates, $55 \%$ were previously identified as nitrated, and of the 244 nitration sites identified, $18 \%$ were previously recognized as targets of nitration. These prior reports confirm both the validity of the ANSID method and its potential for discovery, since many of the nitrated proteins and nitration sites we identified had previously been identified by other groups, as well as the value of the method, since a large number of previously undiscovered proteins and sites were identified.

We also identified 19 nitrated peptides from 13 proteins that were present in at least two out of six $250 \mu \mathrm{M} \mathrm{ONOO}^{-}$-treated rat brain homogenate samples (Table 2), with 4 of these 13 proteins being isoforms of 14-3-3. Of these 19 nitrated peptides, 18 of them were also present in the $1 \mathrm{mM} \mathrm{ONOO}^{-}$group, suggesting that these 18 nitration sites have a particular sensitivity 
to $\mathrm{ONOO}^{-}$, as compared to those found in the other abundant proteins found to be nitrated only with higher concentrations of $\mathrm{ONOO}^{-}$.

Perhaps most importantly, we identified three nitrated peptides from three proteins in untreated rat brain homogenates, demonstrating that the ANSID method is capable of identifying endogenously nitrated proteins and their sites of nitration. These results also demonstrate that aromatic nitration occurs not only during pathological conditions, but can also occur in the setting of normal physiology, a possibility that has been the subject of considerable debate among protein nitration investigators (Turko and Murad, 2002; Schopfer et al., 2003; Gow et al., 2004). The three proteins identified as being endogenously nitrated in this study were 14-3-3 protein gamma, actin, and seipin. Although little is known about the function of seipin, it is highly expressed in the brain, and inheritance of mutated forms of the seipin gene have been shown to cause a number of human disorders, including Berardinelli-Seip congenital lipodystrophy, autosomal-dominant distal hereditary motor neuropathy type $\mathrm{V}$ and Silver syndrome. Thus, the revelation that seipin can be nitrated under physiological conditions may have biological relevance. The fact that nitrated 14-3-3 protein was observed in our untreated brains may also have biological significance. 14-33 is a regulatory protein that has been shown to bind over 100 proteins, including many proteins involved in cell signaling via phosphorylation (Mhawech, 2005). Given our observation that 14-3-3 protein becomes nitrated during physiological conditions, it is worth investigating whether 14-3-3 protein may reside in cells in proximity to one or more NOS isoforms, placing it in proximity to endogenously formed NO.

Importantly, these results also allowed for the identification of proteins nitrated on Trp residues. It is worth noting that two of the three Trp-nitrated proteins that were identified in the $\mathrm{ONOO}^{-}$-treated rat brain homogenates (L-lactate dehydrogenase $\mathrm{B}$ chain and phosphoglycerate kinase 1) were also identified using a 2D-Gel electrophoresis technique employing an anti-6-nitrotryptophan antibody (Uda et al., 2012), although this prior report did not allow for the identification of the specifically modified Trp residues as accomplished using the ANSID method. We anticipate that the ANSID method will greatly aid in the investigation of these relatively understudied Trp-nitrated protein modifications.

We adapted the ANSID method to allow for the relative quantification of the nitrated peptides by performing a dimethylation step with heavy vs. light formaldehyde (Figure 4). Because the stable-isotope labeling that results from this quantitative ANSID approach results in the replacement of at least four hydrogen atoms with at least four deuterium atoms per peptide, there was some concern that chromatographic isotope effects might diminish the accuracy of the relative quantification performed in this method (Gevaert et al., 2008). Notably, deuterium atoms are slightly more hydrophilic than hydrogen atoms, which means that deuterium-containing peptides could potentially elute from the stationary phase slightly earlier than their hydrogen-containing counterparts during
LC-MS/MS analysis. This could in-turn cause discrepancies in the ionization efficiencies of these related peptides, mainly due to matrix interference by co-eluting substances (Taylor, 2005). However, an analysis of the retention times of the heavy and light versions of the nitrated rat brain peptide depicted in Figure 4B (GHyTEGAELVDSVLDVVR) reveals no differences in elution patterns, as the elution of heavy GHyTEGAELVDSVLDVVR occurred at a retention time (32.112-32.887 min) indistinguishable from the light peptide. This observation that differential dimethylation with heavy and light formaldehyde does not result in significant chromatographic isotope effects has been reported previously (Ji et al., 2005), including in the report by Guo et al., which also utilized isotope-coded reductive dimethylation for the relative quantification of nitrated proteins (Guo et al., 2012).

In conclusion, the ANSID approach described here offers a new method for the unbiased identification and quantification of nitrated proteins and their sites of nitration in biologicallycomplex mixtures of proteins. The method provides several significant enhancements over the previously reported insolution enrichment strategies for nitration site identification, including relative quantification, increased sensitivity and the ability to identify Trp-nitrated proteins and sites. While further advances may be necessary to comprehensively identify a majority of the nitration sites present in endogenous tissues, we expect that the ANSID method will greatly aid researchers in their study of protein nitration and the potential roles of this posttransltional modification in disease pathogenesis and normal physiology.

\section{AUTHOR CONTRIBUTIONS}

This study was designed and managed by TN and SG. Experiments were performed by TN, JW, EM, and NB. Mass spectrometry was performed by TN, JW, and YM. Further data interpretation and analysis was performed by TN, JW, and YM. The paper was written by TN and SG.

\section{ACKNOWLEDGMENTS}

The authors are grateful to Drs. Ruba Deeb and Guoqiang Xu for their regular advice and support during the course of this study. We would also like to thank Mark Werner for his continuous aid in maintaining the Mass Spectrometer used in these studies. This work was supported by National Institutes of Health grants to SG (R37 HL087062, U01 HL121828, and T32 GM073546) and a predoctoral fellowship from the National Institute of Health to TN (F31 AG 032195).

\section{SUPPLEMENTARY MATERIAL}

The Supplementary Material for this article can be found online at: http://journal.frontiersin.org/article/10.3389/fchem. 2015.00070 


\section{REFERENCES}

Abello, N., Barroso, B., Kerstjens, H. A., Postma, D. S., and Bischoff, R. (2010). Chemical labeling and enrichment of nitrotyrosine-containing peptides. Talanta 80, 1503-1512. doi: 10.1016/j.talanta.2009.02.002

Abello, N., Kerstjens, H. A., Postma, D. S., and Bischoff, R. (2009). Protein tyrosine nitration: selectivity, physicochemical and biological consequences, denitration, and proteomics methods for the identification of tyrosine-nitrated proteins. J. Proteome Res. 8, 3222-3238. doi: 10.1021/pr900039c

Alvarez, B., Demicheli, V., Durán, R., Trujillo, M., Cerveñansky, C., Freeman, B. A., et al. (2004). Inactivation of human $\mathrm{Cu}, \mathrm{Zn}$ superoxide dismutase by peroxynitrite and formation of histidinyl radical. Free Radic. Biol. Med. 37, 813-822. doi: 10.1016/j.freeradbiomed.2004.06.006

Alvarez, B., and Radi, R. (2003). Peroxynitrite reactivity with amino acids and proteins. Amino Acids 25, 295-311. doi: 10.1007/s00726-003-0018-8

Aulak, K. S., Miyagi, M., Yan, L., West, K. A., Massillon, D., Crabb, J. W., et al. (2001). Proteomic method identifies proteins nitrated in vivo during inflammatory challenge. Proc. Natl. Acad. Sci. U.S.A. 98, 12056-12061. doi: 10.1073/pnas.221269198

Balabanli, B., Kamisaki, Y., Martin, E., and Murad, F. (1999). Requirements for heme and thiols for the nonenzymatic modification of nitrotyrosine. Proc. Natl. Acad. Sci. U.S.A. 96, 13136-13141. doi: 10.1073/pnas.96.23.13136

Beal, M. F. (2002). Oxidatively modified proteins in aging and disease. Free Radic. Biol. Med. 32, 797-803. doi: 10.1016/S0891-5849(02)00780-3

Castegna, A., Thongboonkerd, V., Klein, J. B., Lynn, B., Markesbery, W. R., and Butterfield, D. A. (2003). Proteomic identification of nitrated proteins in Alzheimer's disease brain. J. Neurochem. 85, 1394-1401. doi: 10.1046/j.14714159.2003.01786.x

Danielson, S. R., Held, J. M., Schilling, B., Oo, M., Gibson, B. W., and Andersen, J. K. (2009). Preferentially increased nitration of alpha-synuclein at tyrosine-39 in a cellular oxidative model of Parkinson's disease. Anal. Chem. 81, 7823-7828. doi: $10.1021 /$ ac901176t

Doulias, P. T., Greene, J. L., Greco, T. M., Tenopoulou, M., Seeholzer, S. H., Dunbrack, R. L., et al. (2010). Structural profiling of endogenous Snitrosocysteine residues reveals unique features that accommodate diverse mechanisms for protein S-nitrosylation. Proc. Natl. Acad. Sci. U.S.A. 107, 16958-16963. doi: 10.1073/pnas.1008036107

Dremina, E. S., Li, X., Galeva, N. A., Sharov, V. S., Stobaugh, J. F., and Schöneich, C. (2011). A methodology for simultaneous fluorogenic derivatization and boronate affinity enrichment of 3-nitrotyrosine-containing peptides. Anal. Biochem. 418, 184-196. doi: 10.1016/j.ab.2011.07.024

Ferger, B., Themann, C., Rose, S., Halliwell, B., and Jenner, P. (2001). 6hydroxydopamine increases the hydroxylation and nitration of phenylalanine in vivo: implication of peroxynitrite formation. J. Neurochem. 78, 509-514. doi: 10.1046/j.1471-4159.2001.00429.x

Ferrante, R. J., Hantraye, P., Brouillet, E., and Beal, M. F. (1999). Increased nitrotyrosine immunoreactivity in substantia nigra neurons in MPTP treated baboons is blocked by inhibition of neuronal nitric oxide synthase. Brain Res. 823, 177-182. doi: 10.1016/S0006-8993(99)01166-X

Gevaert, K., Impens, F., Ghesquière, B., Van Damme, P., Lambrechts, A., and Vandekerckhove, J. (2008). Stable isotopic labeling in proteomics. Proteomics 8, 4873-4885. doi: 10.1002/pmic.200800421

Ghesquière, B., Colaert, N., Helsens, K., Dejager, L., Vanhaute, C., Verleysen, $\mathrm{K}$., et al. (2009). In vitro and in vivo protein-bound tyrosine nitration characterized by diagonal chromatography. Mol. Cell. Proteomics 8, 2642-2652. doi: 10.1074/mcp.M900259-MCP200

Ghesquière, B., Goethals, M., Van Damme, J., Staes, A., Timmerman, E., Vandekerckhove, J., et al. (2006). Improved tandem mass spectrometric characterization of 3-nitrotyrosine sites in peptides. Rapid Commun. Mass Spectrom. 20, 2885-2893. doi: 10.1002/rcm.2676

Gidley, M. J., and Sanders, J. K. (1982). Reductive methylation of proteins with sodium cyanoborohydride. Identification, suppression and possible uses of N-cyanomethyl by-products. Biochem. J. 203, 331-334. doi: 10.1042/bj2030331

Gow, A. J., Farkouh, C. R., Munson, D. A., Posencheg, M. A., and Ischiropoulos, H. (2004). Biological significance of nitric oxide-mediated protein modifications. Am. J. Physiol. Lung Cell. Mol. Physiol. 287, L262-L268. doi: 10.1152/ajplung.00295.2003
Guo, J., Prokai-Tatrai, K., and Prokai, L. (2012). Relative quantitation of protein nitration by liquid chromatography-mass spectrometry using isotope-coded dimethyl labeling and chemoprecipitation. J. Chromatogr. A 1232, 266-275. doi: 10.1016/j.chroma.2011.12.100

Hao, G., Derakhshan, B., Shi, L., Campagne, F., and Gross, S. S. (2006). SNOSID, a proteomic method for identification of cysteine $\mathrm{S}$-nitrosylation sites in complex protein mixtures. Proc. Natl. Acad. Sci. U.S.A. 103, 1012-1017. doi: 10.1073/pnas.0508412103

Harrison, D., Griendling, K. K., Landmesser, U., Hornig, B., and Drexler, H. (2003). Role of oxidative stress in atherosclerosis. Am. J. Cardiol. 91, 7A-11A. doi: 10.1016/S0002-9149(02)03144-2

Ishii, Y., Iijima, M., Umemura, T., Nishikawa, A., Iwasaki, Y., Ito, R., et al. (2006) Determination of nitrotyrosine and tyrosine by high-performance liquid chromatography with tandem mass spectrometry and immunohistochemical analysis in livers of mice administered acetaminophen. J. Pharm. Biomed. Anal. 41, 1325-1331. doi: 10.1016/j.jpba.2006.02.045

Ishii, Y., Ogara, A., Katsumata, T., Umemura, T., Nishikawa, A., Iwasaki, Y., et al. (2007). Quantification of nitrated tryptophan in proteins and tissues by high-performance liquid chromatography with electrospray ionization tandem mass spectrometry. J. Pharm. Biomed. Anal. 44, 150-159. doi: 10.1016/j.jpba.2007.01.012

Ji, C., Guo, N., and Li, L. (2005). Differential dimethyl labeling of N-termini of peptides after guanidination for proteome analysis. J. Proteome Res. 4, 2099-2108. doi: 10.1021/pr050215d

Kalkhof, S., and Sinz, A. (2008). Chances and pitfalls of chemical cross-linking with amine-reactive N-hydroxysuccinimide esters. Anal. Bioanal. Chem. 392, 305-312. doi: 10.1007/s00216-008-2231-5

Kanski, J., Behring, A., Pelling, J., and Schöneich, C. (2005a). Proteomic identification of 3-nitrotyrosine-containing rat cardiac proteins: effects of biological aging. Am. J. Physiol. Heart Circ. Physiol. 288, H371-H381. doi: 10.1152/ajpheart.01030.2003

Kanski, J., Hong, S. J., and Schöneich, C. (2005b). Proteomic analysis of protein nitration in aging skeletal muscle and identification of nitrotyrosinecontaining sequences in vivo by nanoelectrospray ionization tandem mass spectrometry. J. Biol. Chem. 280, 24261-24266. doi: 10.1074/jbc.M5017 73200

Kanski, J., and Schöneich, C. (2005). Protein nitration in biological aging: proteomic and tandem mass spectrometric characterization of nitrated sites. Methods Enzymol. 396, 160-171. doi: 10.1016/S0076-6879(05)9 6016-3

Li, B., Held, J. M., Schilling, B., Danielson, S. R., and Gibson, B. W. (2011). Confident identification of 3-nitrotyrosine modifications in mass spectral data across multiple mass spectrometry platforms. J. Proteomics 74, 2510-2521. doi: 10.1016/j.jprot.2011.04.007

Means, G. E., and Feeney, R. E. (1995). Reductive alkylation of proteins. Anal. Biochem. 224, 1-16. doi: 10.1006/abio.1995.1001

Mhawech, P. (2005). 14-3-3 proteins-an update. Cell Res. 15, 228-236. doi: $10.1038 /$ sj.cr.7290291

Miller, B. T. (1996). Acylation of peptide hydroxyl groups with the BoltonHunter reagent. Biochem. Biophys. Res. Commun. 218, 377-382. doi: 10.1006/bbrc.1996.0066

Miller, B. T., Collins, T. J., Rogers, M. E., and Kurosky, A. (1997). Peptide biotinylation with amine-reactive esters: differential side chain reactivity. Peptides 18, 1585-1595. doi: 10.1016/S0196-9781(97)00225-8

Nikov, G., Bhat, V., Wishnok, J. S., and Tannenbaum, S. R. (2003). Analysis of nitrated proteins by nitrotyrosine-specific affinity probes and mass spectrometry. Anal. Biochem. 320, 214-222. doi: 10.1016/S00032697(03)00359-2

Nuriel, T., Deeb, R. S., Hajjar, D. P., and Gross, S. S. (2008). Protein 3nitrotyrosine in complex biological samples: quantification by high-pressure liquid chromatography/electrochemical detection and emergence of proteomic approaches for unbiased identification of modification sites. Methods Enzymol. 441, 1-17. doi: 10.1016/S0076-6879(08)01201-9

Ong, S. E., and Mann, M. (2005). Mass spectrometry-based proteomics turns quantitative. Nat. Chem. Biol. 1, 252-262. doi: 10.1038/nchembio736

Pacher, P., Beckman, J. S., and Liaudet, L. (2007). Nitric oxide and peroxynitrite in health and disease. Physiol. Rev. 87, 315-424. doi: 10.1152/physrev.00029.2006 
Patel, R. P., Moellering, D., Murphy-Ullrich, J., Jo, H., Beckman, J. S., and DarleyUsmar, V. M. (2000). Cell signaling by reactive nitrogen and oxygen species in atherosclerosis. Free Radic. Biol. Med. 28, 1780-1794. doi: 10.1016/S08915849(00)00235-5

Patterson, S. D. (2001). Protein identification and characterization by mass spectrometry. Curr. Protoc. Mol. Biol. Chapter 10, Unit 10.22. doi: 10.1002/0471142727.mb1022s41

Peluffo, G., and Radi, R. (2007). Biochemistry of protein tyrosine nitration in cardiovascular pathology. Cardiovasc. Res. 75, 291-302. doi: 10.1016/j.cardiores.2007.04.024

Prokai-Tatrai, K., Guo, J., and Prokai, L. (2011). Selective chemoprecipitation and subsequent release of tagged species for the analysis of nitropeptides by liquid chromatography-tandem mass spectrometry. Mol. Cell. Proteomics 10:M110.002923. doi: 10.1074/mcp.M110.002923

Rayment, I. (1997). Reductive alkylation of lysine residues to alter crystallization properties of proteins. Methods Enzymol. 276, 171-179. doi: 10.1016/S00766879(97)76058-0

Rebrin, I., Brégère, C., Kamzalov, S., Gallaher, T. K., and Sohal, R. S. (2007). Nitration of tryptophan 372 in succinyl-CoA:3-ketoacid CoA transferase during aging in rat heart mitochondria. Biochemistry 46, 10130-10144. doi: 10.1021/bi7001482

Reed, T. T., Pierce, W. M. Jr., Turner, D. M., Markesbery, W. R., and Butterfield, D. A. (2009). Proteomic identification of nitrated brain proteins in early Alzheimer's disease inferior parietal lobule. J. Cell. Mol. Med. 13, 2019-2029. doi: 10.1111/j.1582-4934.2008.00478.x

Reynolds, M. R., Berry, R. W., and Binder, L. I. (2007). Nitration in neurodegeneration: deciphering the "Hows" "nYs." Biochemistry 46, 7325-7336. doi: 10.1021/bi700430y

Robinson, R. A., and Evans, A. R. (2012). Enhanced sample multiplexing for nitrotyrosine-modified proteins using combined precursor isotopic labeling and isobaric tagging. Anal. Chem. 84, 4677-4686. doi: 10.1021/ac202000v

Rubbo, H., Batthyany, C., and Radi, R. (2000). Nitric oxide-oxygen radicals interactions in atherosclerosis. Biol. Res. 33, 167-175. doi: 10.4067/S071697602000000200017

Sacksteder, C. A., Qian, W. J., Knyushko, T. V., Wang, H., Chin, M. H., Lacan, G., et al. (2006). Endogenously nitrated proteins in mouse brain: links to neurodegenerative disease. Biochemistry 45, 8009-8022. doi: 10.1021/bi060474w

Schopfer, F. J., Baker, P. R., and Freeman, B. A. (2003). NO-dependent protein nitration: a cell signaling event or an oxidative inflammatory response? Trends Biochem. Sci. 28, 646-654. doi: 10.1016/j.tibs.2003. 10.006

Stevens, S. M. Jr., Prokai-Tatrai, K., and Prokai, L. (2008). Factors that contribute to the misidentification of tyrosine nitration by shotgun proteomics. Mol. Cell. Proteomics 7, 2442-2451. doi: 10.1074/mcp.M800065-MCP200

Sultana, R., Poon, H. F., Cai, J., Pierce, W. M., Merchant, M., Klein, J. B., et al. (2006). Identification of nitrated proteins in Alzheimer's disease brain using a redox proteomics approach. Neurobiol. Dis. 22, 76-87. doi: 10.1016/j.nbd.2005.10.004

Sultana, R., Reed, T., Perluigi, M., Coccia, R., Pierce, W. M., and Butterfield, D. A. (2007). Proteomic identification of nitrated brain proteins in amnestic mild cognitive impairment: a regional study. J. Cell. Mol. Med. 11, 839-851. doi: 10.1111/j.1582-4934.2007.00065.x

Taylor, P. J. (2005). Matrix effects: the Achilles heel of quantitative highperformance liquid chromatography-electrospray-tandem mass spectrometry. Clin. Biochem. 38, 328-334. doi: 10.1016/j.clinbiochem.2004.11.007

Tsumoto, H., Taguchi, R., and Kohda, K. (2010). Efficient identification and quantification of peptides containing nitrotyrosine by matrix-assisted laser desorption/ionization time-of-flight mass spectrometry after derivatization. Chem. Pharm. Bull. 58, 488-494. doi: 10.1248/cpb.58.488

Turko, I. V., and Murad, F. (2002). Protein nitration in cardiovascular diseases. Pharmacol. Rev. 54, 619-634. doi: 10.1124/pr.54.4.619

Uda, M., Kawasaki, H., Shigenaga, A., Baba, T., and Yamakura, F. (2012). Proteomic analysis of endogenous nitrotryptophan-containing proteins in rat hippocampus and cerebellum. Biosci. Rep. 32, 521-530. doi: 10.1042/BSR20120032

van der Loo, B., Labugger, R., Skepper, J. N., Bachschmid, M., Kilo, J., Powell, J. M., et al. (2000). Enhanced peroxynitrite formation is associated with vascular aging. J. Exp. Med. 192, 1731-1744. doi: 10.1084/jem.192.12.1731

Yamakura, F., Matsumoto, T., Ikeda, K., Taka, H., Fujimura, T., Murayama, K., et al. (2005). Nitrated and oxidized products of a single tryptophan residue in human $\mathrm{Cu}, \mathrm{Zn}$-superoxide dismutase treated with either peroxynitrite-carbon dioxide or myeloperoxidase-hydrogen peroxide-nitrite. J. Biochem. 138, 57-69. doi: 10.1093/jb/mvi095

Zhang, Q., Qian, W. J., Knyushko, T. V., Clauss, T. R., Purvine, S. O., Moore, R. J., et al. (2007). A method for selective enrichment and analysis of nitrotyrosine-containing peptides in complex proteome samples. J. Proteome Res. 6, 2257-2268. doi: 10.1021/pr0606934

Zhou, P., Qian, L., Gallo, E. F., Deeb, R. S., Anrather, J., Gross, S. S., et al. (2011). The scavenger receptor CD36 contributes to the neurotoxicity of bone marrow-derived monocytes through peroxynitrite production. Neurobiol. Dis. 42, 292-299. doi: 10.1016/j.nbd.2011.01.019

Conflict of Interest Statement: The authors declare that the research was conducted in the absence of any commercial or financial relationships that could be construed as a potential conflict of interest.

Copyright (C) 2016 Nuriel, Whitehouse, Ma, Mercer, Brown and Gross. This is an open-access article distributed under the terms of the Creative Commons Attribution License (CC BY). The use, distribution or reproduction in other forums is permitted, provided the original author(s) or licensor are credited and that the original publication in this journal is cited, in accordance with accepted academic practice. No use, distribution or reproduction is permitted which does not comply with these terms. 